BIOFARM

Jurnal Ilmiah Pertanian

ISSN Print: 0216-5430; ISSN Online: 2301-6442

Vol. 14, No. 1, April 2018

\title{
Pengaruh Intensitas Cahaya dan Macam Pupuk Kandang terhadap Pertumbuhan dan Produksi Tanaman Sawi Putih (Brassica pekinensia L)
}

\section{The Effect Of Light Intensity And Kinds Of Manure On The Growth And Production Of Chinese Cabbage (Brassica Pekinensia L)}

\author{
Afif Lathifah* dan Syakiroh Jazilah \\ Program Studi Agroteknologi, Fakultas Pertanian, Universitas Pekalongan \\ *Korespondensi Penulis: iffah.lathifah13@gmail.com
}

\begin{abstract}
ABSTRAK
Sawi putih (Brassica pekinensia L) merupakan sayuran dari suku kubis-kubisan (Brassicaceae) yang berasal dari Tiongkok dan Asia Timur. Penelitian bertujuan untuk mengetahui pengaruh intensitas cahaya dan macam pupuk kandang serta interaksinya terhadap pertumbuhan dan produksi tanaman sawi putih, telah dilakukan di Desa Sempu, Limpung, Batang. Rancangan percobaan yang digunakan adalah rancangan petak terbagi (splitplot design). Faktor pertama (main plot) adalah intensitas cahaya $(25 \%, 50 \%, 75 \%, 100 \%$ ), faktor kedua (sub plot) adalah macam pupuk kandang (ayam, kambing, sapi). Variabel pengamatan meliputi tinggi tanaman, panjang akar terpanjang, jumlah akar, bobot tanaman tanpa akar, jumlah daun, luas daun, bobot basah tanaman, bobot kering tanaman dan intensitas serangan hama dan penyakit. Hasil penelitian menunjukkan intensitas cahaya berpengaruh sangat nyata terhadap semua variabel, berpengaruh nyata pada intensitas serangan hama dan penyakit. Intensitas cahaya terbaik adalah intensitas cahaya $100 \%$. Macam pupuk kandang berpengaruh sangat nyata pada semua variabel, berpengaruh nyata pada tinggi tanaman dan tidak berpengaruh nyata pada intensitas serangan hama dan penyakit. Macam pupuk kandang terbaik adalah pupuk kandang ayam. Terdapat interaksi yang sangat nyata antara intensitas cahaya dan macam pupuk kandang terhadap semua variabel, berpengaruh nyata pada jumlah daun dan tidak berpengaruh nyata pada intensitas serangan hama dan penyakit. Kombinasi terbaik diperoleh pada intensitas cahaya $100 \%$ dengan macam pupuk kandang ayam.
\end{abstract}

Kata kunci: sawi putih, intensitas cahaya, macam pupuk kandang

\section{ABSTRACT}

Chinese cabbage (Brassica pekinensia $L$ ) is a vegetable from the tribe of cabbage (Brassicaceae) which comes from China and East Asia. The research aims to determinate the effect of light intensity and kinds of manure and their interactions on the growth and production of chinese cabbage, was conducted in the village of Sempu, Limpung, Batang. The experimental design used was split plot design. The first factor (main plot) is the light intensity $(25 \%, 50 \%$, $75 \%, 100 \%$ ), the second factor (sub plot) is a kinds of manure (chicken, goat, cow). The observation variables include plant height, the longest root length, number of roots, the weight of the plant without roots, number of leaves, leaf area, plant fresh weight, plant dry weight and the intensity of pests and diseases. The results showed the light intensity very significant effect on all variables, significantly effect on the intensity of pests and diseases. The best light intensity is light intensity $100 \%$. Kinds of manure a very significant effect on all variables, significant effect on plant height and not significantly different on the intensity of pests and diseases. The best kind of manure is chicken manure. There is a very significant interaction between the light intensity and kinds of manure to all variables, significantly effect on the number of leaves and not significantly different on the intensity of pests and diseases. The best combination is obtained light intensity $100 \%$ with a kind of chicken manure.

Keywords: Chinese cabbage, light intensity, kinds of manure

\section{PENDAHULUAN}

Tanaman sawi putih bukan tanaman asli Indonesia, diperkirakan berasal dari Tiongkok dan Asia Timur, oleh karena itu tanaman sawi putih diberi sebutan Chinese cabbage atau Kubis Cina. Budidaya sawi putih di Indonesia diduga dimulai pada abad XIX bersamaan dengan lintas perdagangan jenis sayuran sub tropis lainnya dari kelompok (famili) kubis - kubisan (Cruciferae). Pada mulanya daerah pusat penyebarannya adalah di Jawa Barat (Lembang, Cipanas, Pangalengan) dan di Jawa Timur (Malang dan Tosari). Kini pe- 
nyebaran tanaman sawi putih sudah meluas di berbagai daerah di Indonesia, terutama daerah-daerah yang mempunyai ketinggian di atas $1000 \mathrm{~m}$ dpl (Cahyono, 2003).

Sawi putih sudah sangat populer di masyarakat dan termasuk komoditas yang digemari (banyak dikonsumsi) oleh masyarakat diantara sawi jenis lainnya, karena memiliki rasa agak manis, renyah, dan paling enak, sehingga permintaan jenis sayuran ini sangat besar. Permintaan sawi putih di pasaran akan meningkat terus setiap tahun sejalan dengan pertumbuhan ekonomi, pertumbuhan jumlah penduduk, dan pertumbuhan pendapatan masyarakat, baik untuk keperluan makanan, pengobatan, ataupun lainnya (Cahyono, 2003). Salah satu upaya yang dilakukan untuk meningkatkan produksi tanaman sawi putih khususnya di dataran rendah adalah dengan memanipulasi teknik budidaya yaitu dengan pengaturan intensitas cahaya dan penggunaan pupuk kandang.

Menurut Sastradihardja (2014) tanaman akan tumbuh baik jika memperoleh sinar matahari yang cukup, akan tetapi banyaknya sinar matahari yang dibutuhkan setiap jenis tanaman berbeda. Tanaman yang menghasilkan bunga atau buah pada umunya membutuhkan sinar matahari penuh atau dengan kata lain tidak boleh ternaungi, sedangkan tanaman yang menghasilkan daun masih dapat tumbuh walaupun sinar matahari sedikit atau ternaungi. Budidaya tanaman di bawah naungan (protected cultivation) adalah teknik penanaman sayuran yang dapat mengatasi masalah yang berhubungan dengan penanaman sayuran di lahan terbuka. Teknik ini merupakan usaha perlindungan fisik dari tanaman dengan tujuan utama untuk mengendalikan faktor cuaca yang mengganggu perkembangan tanaman. Keuntungan lainnya adalah efisiensi penggunaan pupuk dan pestisida, penggunaan teknik perlindungan tanaman secara biologi dan produksi tanaman lebih terencana (Gunadi dkk., 2006).

Samekto (2006) menyatakan salah satu alternatif untuk mempertahankan dan meningkatkan kesuburan tanah adalah dengan pemberian bahan organik seperti pupuk kandang ke dalam tanah. Pemupukan bertujuan untuk memelihara dan memperbaiki kesuburan tanah dengan memberikan unsur atau zat hara ke dalam tanah yang secara langsung atau tidak dapat menyumbangkan bahan makanan pada tanaman. Pemupukan juga akan memperbaiki $\mathrm{pH}$ dan lingkungan tanah sebagai tempat tumbuh tanaman. Setiap jenis hewan menghasilkan kotoran dengan kandungan hara yang berbeda, namun secara umum kotoran hewan mengandung unsur hara makro seperti nitrogen $(\mathrm{N})$, fosfor $(\mathrm{P})$, kalium $(\mathrm{K})$, kalsium $(\mathrm{Ca})$, magnesium (Mg) dan belerang (S) (Risnandar, 2012).

Penelitian ini dilakukan dengan tujuan untuk mengetahui intensitas cahaya yang optimum untuk meningkatkan pertumbuhan dan produksi tanaman sawi putih, untuk mengetahui macam pupuk kandang yang tepat untuk meningkatkan pertumbuhan dan produksi tanaman sawi putih, serta untuk mengetahui interaksi antara intensitas cahaya dan macam pupuk kandang sehingga dapat meningkatkan pertumbuhan dan produksi tanaman sawi putih.

\section{BAHAN DAN METODE}

Percobaan telah dilaksanakan selama 3 bulan yaitu mulai bulan April sampai Juni 2016, di Desa Sempu, Kecamatan Limpung, Kabupaten Batang dengan ketinggian tempat $291 \mathrm{~m}$ dpl. Rancangan yang akan digunakan dalam percobaan ini adalah Rancangan Petak Terbagi (Splitplot design) dengan tiga ulangan yang terdiri atas dua faktor. Intensitas cahaya dialokasikan sebagai main plot dan macam pupuk kandang dialokasikan sebagai sub plot. Intensitas cahaya yang terdiri atas 11: Intensitas Cahaya 25\%, 12 : Intensitas Cahaya 50\%, I3 : Intensitas Cahaya 75\% dan 14 : Intensitas Cahaya 100\%. Macam pupuk kandang yang terdiri atas $\mathrm{K} 1$ : Pupuk Kandang Ayam, K2 : Pupuk Kandang 
Kambing dan K3 : Pupuk Kandang Sapi. Dengan demikian terdapat 12 kombinasi perlakuan, masing-masing kombinasi diulang tiga kali sehingga seluruhnya ada $(4 \times 3) \times 3=36$ satuan percobaan.

Variabel yang diamati meliputi : tinggi tanaman, panjang akar terpanjang, jumlah akar, bobot tanaman tanpa akar, jumlah daun, luas daun, bobot basah tanaman, bobot kering tanaman dan intensitas serangan hama dan penyakit. Data yang diperoleh dianalisis dengan Uji F. Jika antara faktor yang dicoba terdapat beda nyata maka dilanjutkan dengan Uji BNT $5 \%$. Faktor intensitas cahaya dianalisis dengan menggunakan uji regresi, sedangkan macam pupuk kandang dianalisis dengan menggunakan uji kontras orthogonal.

\section{HASIL DAN PEMBAHASAN}

\section{Pengaruh intensitas cahaya}

Hasil penelitian menunjukkan bahwa perlakuan intensitas cahaya berbeda sangat nyata terhadap variabel tinggi tanaman, panjang akar terpanjang, jumlah akar, bobot tanaman tanpa akar, jumlah

Tabel 1. Angka Rata-rata dan Analisis Statistik Data Komponen Pertumbuhan dan Produksi Tanaman Sawi Putih.

\begin{tabular}{|c|c|c|c|c|c|}
\hline Perlakuan & $\begin{array}{l}\text { Tinggi } \\
\text { tanaman } \\
\text { (cm) }\end{array}$ & $\begin{array}{l}\text { Panjang akar } \\
\text { terpanjang } \\
\text { (cm) }\end{array}$ & $\begin{array}{l}\text { Jumlah } \\
\text { akar } \\
\text { (buah) }\end{array}$ & $\begin{array}{c}\text { Bobot } \\
\text { tanaman } \\
\text { tanpa akar } \\
\text { (gram) }\end{array}$ & $\begin{array}{l}\text { Jumlah } \\
\text { daun } \\
\text { (helai) }\end{array}$ \\
\hline \multicolumn{6}{|l|}{ Intensitas Cahaya (I) } \\
\hline$I_{1}:$ Intensitas Cahaya $25 \%$ & $16,07 \mathrm{a}$ & $48,31 \mathrm{~b}$ & $13,18 \mathrm{a}$ & 71,85 a & $14,07 \mathrm{a}$ \\
\hline$I_{2}:$ Intensitas Cahaya $50 \%$ & $18,24 \mathrm{~b}$ & $47,10 \mathrm{a}$ & $19,93 \mathrm{~b}$ & $103,57 \mathrm{~b}$ & $14,73 \mathrm{a}$ \\
\hline$I_{3}:$ Intensitas Cahaya 75\% & $21,61 \mathrm{c}$ & $57,59 \mathrm{c}$ & $28,38 \mathrm{c}$ & $276,48 \mathrm{c}$ & $19,09 \mathrm{~b}$ \\
\hline$I_{4}:$ Intensitas Cahaya $100 \%$ & $22,01 \mathrm{c}$ & $61,13 d$ & $39,78 \mathrm{~d}$ & $361,16 \mathrm{~d}$ & $22,11 \mathrm{c}$ \\
\hline F hitung & $10,49^{* \star}$ & $270,43^{\star \star}$ & $74,08^{\star \star}$ & $265,55^{\star \star}$ & $15,89^{\star \star}$ \\
\hline$F$ tabel $5 \%$ & 4,76 & 4,76 & 4,76 & 4,76 & 4,76 \\
\hline $\mathrm{F}$ tabel $1 \%$ & 9,78 & 9,78 & 9,78 & 9,78 & 9,78 \\
\hline BNT 5\% & 5,24 & 2,52 & 7,99 & 50,92 & 5,38 \\
\hline KK (\%) & 0,13 & 0,02 & 0,16 & 0,13 & 0,15 \\
\hline \multicolumn{6}{|l|}{ Macam Pupuk Kandang (K) } \\
\hline K1 : Pupuk Kandang Ayam & $20,19 \mathrm{c}$ & $56,33 \mathrm{~b}$ & $28,37 \mathrm{c}$ & $218,75 \mathrm{c}$ & $18,23 \mathrm{c}$ \\
\hline K2 : Pupuk Kandang Kambing & $18,80 \mathrm{a}$ & $51,99 \mathrm{a}$ & $25,35 \mathrm{~b}$ & $191,70 \mathrm{a}$ & $17,22 \mathrm{a}$ \\
\hline K3 : Pupuk Kandang Sapi & $19,46 \mathrm{~b}$ & $52,28 \mathrm{a}$ & $22,23 a$ & $199,34 \mathrm{~b}$ & $17,80 \mathrm{~b}$ \\
\hline F hitung & $5,97^{*}$ & $27,38^{\star \star}$ & $16,47^{\star \star}$ & $26,05^{\star \star}$ & $45,34^{\star *}$ \\
\hline$F$ tabel $5 \%$ & 3,63 & 3,63 & 3,63 & 3,63 & 3,63 \\
\hline $\mathrm{F}$ tabel $1 \%$ & 6,23 & 6,23 & 6,23 & 6,23 & 6,23 \\
\hline BNT 5\% & 1,70 & 2,78 & 5,23 & 16,38 & 0,45 \\
\hline KK (\%) & 0,05 & 0,03 & 0,10 & 0,05 & 0,01 \\
\hline
\end{tabular}

daun, luas daun, bobot basah tanaman dan bobot kering tanaman, sedangkan pada intensitas serangan hama dan penyakit berbeda nyata. Intensitas cahaya $100 \%$ (I4) memberikan hasil tertinggi pada partumbuhan dan produksi tanaman sawi putih.

Menurut Cahyono (2003) tanaman sawi putih memerlukan intensitas cahaya matahari yang tinggi dengan panjang penyinaran matahari (fotoperiodisitas) selama 12 - 16 jam setiap hari untuk pertumbuhannya. Zulkarnain (2010) lebih lanjut menyatakan bahwa penyinaran matahari pada kondisi hari panjang (penyinaran 14-16 jam per hari) akan menghasilkan karbohidrat dan protein dalam jumlah yang besar. Karbohidrat dan protein tersebut kemudian digunakan untuk pertumbuhan dan perkembangan akar, batang dan daun. Tanaman yang memperoleh cahaya cukup akan berwarna hijau yang menandakan adanya klorofil dan aktifitas fotosintesis serta memiliki batang yang normal. 
Keterangan:

Angka-angka dalam kolom dan perlakuan yang diikuti huruf yang sama menunjukkan tidak berbeda nyata berdasarkan Uji BNT taraf 5\%, ** = berbeda sangat nyata, $*=$ berbeda nyata, $\mathrm{tn}=$ tidak berbeda nyata.

Intensitas cahaya matahari mempengaruhi berbagai proses dalam partumbuhan dan perkembangan tanaman, sesuai penelitian Sulistyaningsih, dkk (2003) yang menyatakan bahwa peningkatan intensitas cahaya hingga tingkat optimum meningkatkan laju asimilasi bersih total tanaman sehingga fotosintat yang terbentuk meningkat. Pembentukan fotosintat yang tinggi ini mendorong kecepatan pembentukan organorgan tanaman seperti luas daun. Luas daun yang besar menyebabkan laju asimilasi bersih meningkat, sehingga bobot basah dan kering tanaman meningkat. Bobot tanaman ditentukan oleh translokasi hasil fotosintesis. Fotosintesis akan optimal pada intensitas cahaya yang optimal pula, sehingga akan meningkatkan bobot tanaman. Menurut Ribeiro dkk., (2002), pada temperatur dan cahaya optimal fotosintesis berlangsung lebih cepat dan hasil fotosintesis lebih besar. Selanjutnya Harjadi (1991) menyatakan bahwa besar-

Tabel 2. Angka Rata-rata dan Analisis Statistik Data Komponen Pertumbuhan dan Produksi Tanaman Sawi Putih.

\begin{tabular}{|c|c|c|c|c|}
\hline Perlakuan & $\begin{array}{l}\text { Luas daun } \\
\quad(\mathrm{cm} 2)\end{array}$ & $\begin{array}{c}\text { Bobot basah } \\
\text { tanaman } \\
\text { (gram) }\end{array}$ & $\begin{array}{c}\text { Bobot kering } \\
\text { tanaman } \\
\text { (gram) }\end{array}$ & $\begin{array}{l}\text { Intensitas serangan } \\
\text { hama dan penyakit } \\
(\%)\end{array}$ \\
\hline \multicolumn{5}{|l|}{ Intensitas Cahaya (I) } \\
\hline 11 : Intensitas Cahaya 25\% & $88,51 \mathrm{a}$ & 73,73 a & $2,00 \mathrm{a}$ & $27,15 \mathrm{a}$ \\
\hline 12 : Intensitas Cahaya $50 \%$ & $114,24 \mathrm{~b}$ & $105,95 b$ & $3,14 \mathrm{a}$ & $32,47 \mathrm{~b}$ \\
\hline I3 : Intensitas Cahaya 75\% & $172,82 \mathrm{c}$ & $292,06 \mathrm{c}$ & $12,64 \mathrm{~b}$ & $35,23 \mathrm{bc}$ \\
\hline 14 : Intensitas Cahaya 100\% & $211,25 d$ & $400,98 d$ & $18,51 \mathrm{c}$ & $39,60 \mathrm{c}$ \\
\hline F hitung & $72,25^{\star \star}$ & $392,29^{\star *}$ & $98,81^{\star \star}$ & $5,38^{*}$ \\
\hline $\mathrm{F}$ tabel $5 \%$ & 4,76 & 4,76 & 4,76 & 4,76 \\
\hline $\mathrm{F}$ tabel $1 \%$ & 9,78 & 9,78 & 9,78 & 9,78 \\
\hline BNT 5\% & 39,24 & 46,99 & 4,76 & 13,49 \\
\hline$\overline{\mathrm{KK}}(\%)$ & 0,13 & 0,11 & 0,26 & 0,20 \\
\hline \multicolumn{5}{|l|}{ Macam Pupuk Kandang (K) } \\
\hline K1 : Pupuk Kandang Ayam & $157,85 b$ & $237,88 \mathrm{c}$ & $10,07 \mathrm{c}$ & 33,18 \\
\hline K2 : Pupuk Kandang Kambing & $139,84 a$ & $202,99 a$ & $8,10 \mathrm{a}$ & 29,04 \\
\hline K3 : Pupuk Kandang Sapi & $142,42 \mathrm{a}$ & $213,67 b$ & 9,04 & 38,69 \\
\hline F hitung & $15,07^{\star \star}$ & $39,86^{* *}$ & $11,04^{\star \star}$ & $2,78 \mathrm{tn}$ \\
\hline $\mathrm{F}$ tabel $5 \%$ & 3,63 & 3,63 & 3,63 & 3,63 \\
\hline $\mathrm{F}$ tabel $1 \%$ & 6,23 & 6,23 & 6,23 & 6,23 \\
\hline BNT 5\% & 15,04 & 16,98 & 1,78 & \\
\hline $\mathrm{KK}(\%)$ & 0,06 & 0,04 & 0,11 & 0,30 \\
\hline
\end{tabular}

Keterangan:

Angka-angka dalam kolom dan perlakuan yang diikuti huruf yang sama menunjukkan tidak berbeda nyata

berdasarkan Uji BNT taraf $5 \%, * *=$ berbeda sangat nyata, $*=$ berbeda nyata, $\mathrm{tn}=$ tidak berbeda nyata nya cahaya yang tertangkap pada proses fotosintesis menunjukkan besarnya biomassa tanaman. Semakin besar hasil fotosintesis yang terbentuk, maka pembentukan biomassa juga semakin meningkat.

Intensitas serangan hama dan penyakit tertinggi terdapat pada perlakuan intensitas cahaya 100\% (tanpa naungan). Menurut penelitian Moekasan dan Prabaningrum (2011) penggunaan naungan pada tanaman cabai merah selain untuk mengurangi intensitas cahaya yang sampai ke tanaman pokok, juga dimanfaatkan sebagai salah satu metode pengendalian hama dan penyakit. Hal ini disebabkan beberapa jenis hama yang sangat merugikan tidak dapat menyerang tanaman karena terhalang oleh kasa, selain itu dengan adanya atap yang terbuat dari kasa laju jatuhnya air hujan berkurang, sehingga tidak menimbulkan percikan tanah ke tanaman yang dapat mengurangi insiden serangan penyakit. 


\section{Pengaruh macam pupuk kandang}

Hasil penelitian menunjukkan bahwa macam pupuk kandang berbeda sangat nyata terhadap panjang akar terpanjang, jumlah akar, bobot tanaman tanpa akar, jumlah daun, luas daun, bobot basah tanaman, bobot kering tanaman dan berbeda nyata pada variabel tinggi tanaman sedangkan pada variabel intensitas serangan hama dan penyakit tidak berbeda nyata. Macam pupuk kandang ayam (K1) memberikan hasil tertinggi pada pertumbuhan dan produksi tanaman sawi putih. Hal ini karena kandungan hara pada pupuk kandang ayam lebih tinggi dibanding dengan pupuk kandang kambing dan sapi.
Hardjowigeno (2007) menyatakan pupuk kandang ayam mengandung nitrogen $(\mathrm{N})$ tiga kali lebih besar daripada pupuk kandang lain. Kandungan fosfor $(P)$ pada semua pupuk kandang terdapat dalam kotoran padat, sedangkan sebagian besar kalium $(\mathrm{K})$ dan nitrogen $(\mathrm{N})$ terdapat dalam kotoran cair atau urin. Kandungan kalium (K) dalam urin lima kali lebih banyak dari kotoran padat sedangkan kandungan nitrogen $(\mathrm{N})$ dua sampai tiga kali lebih banyak. Kandungan unsur hara dalam kotoran ayam paling tinggi karena bagian cair atau urin tercampur dengan bagian padat. Pupuk kandang ayam mampu menunjukkan pertumbuhan vegetatif dan generatif yang lebih baik (Arifah, 2013).

Tabel 3. Angka Rata-rata Interaksi antara Intensitas Cahaya dan Macam Pupuk Kandang terhadap Variabel Tinggi Tanaman, Panjang Akar Terpanjang, Jumlah Akar, Bobot Tanaman Tanpa Akar, Jumlah Daun, Luas Daun, Bobot Basah Tanaman dan Bobot Kering Tanaman

\begin{tabular}{lcccc}
\hline Perlakuan & $\begin{array}{c}\text { Tinggi tanaman } \\
(\mathrm{cm})\end{array}$ & $\begin{array}{c}\text { Panjang akar } \\
\text { terpanjang } \\
(\mathrm{cm})\end{array}$ & $\begin{array}{c}\text { Jumlah akar } \\
\text { (buah) }\end{array}$ & $\begin{array}{c}\text { Bobot tanaman } \\
\text { tanpa akar } \\
\text { (gram) }\end{array}$ \\
\hline I1K1 & $17,40 \mathrm{ab}$ & $54,00 \mathrm{~d}$ & $13,93 \mathrm{ab}$ & $73,39 \mathrm{a}$ \\
I1K2 & $15,97 \mathrm{a}$ & $43,20 \mathrm{a}$ & $14,53 \mathrm{abc}$ & $74,07 \mathrm{a}$ \\
I1K3 & $14,85 \mathrm{a}$ & $47,73 \mathrm{bc}$ & $11,07 \mathrm{a}$ & $68,09 \mathrm{a}$ \\
I2K1 & $18,13 \mathrm{abc}$ & $45,40 \mathrm{ab}$ & $18,00 \mathrm{bcd}$ & $79,93 \mathrm{a}$ \\
I2K2 & $16,43 \mathrm{a}$ & $48,13 \mathrm{c}$ & $20,07 \mathrm{~cd}$ & $87,81 \mathrm{a}$ \\
I2K3 & $20,17 \mathrm{bcd}$ & $47,77 \mathrm{bc}$ & $21,73 \mathrm{~d}$ & $142,97 \mathrm{a}$ \\
I3K1 & $22,60 \mathrm{~d}$ & $63,87 \mathrm{f}$ & $35,20 \mathrm{f}$ & $310,08 \mathrm{~d}$ \\
I3K2 & $20,45 \mathrm{bcd}$ & $55,60 \mathrm{~d}$ & $28,33 \mathrm{e}$ & $269,27 \mathrm{c}$ \\
I3K3 & $21,78 \mathrm{~d}$ & $53,30 \mathrm{~d}$ & $21,60 \mathrm{~d}$ & $250,09 \mathrm{c}$ \\
I4K1 & $22,63 \mathrm{~d}$ & $62,07 \mathrm{ef}$ & $46,33 \mathrm{~g}$ & $411,61 \mathrm{e}$ \\
I4K2 & $22,37 \mathrm{~d}$ & $61,03 \mathrm{ef}$ & $38,47 \mathrm{f}$ & $335,66 \mathrm{~d}$ \\
I4K3 & $21,03 \mathrm{~cd}$ & $60,30 \mathrm{e}$ & $35,43 \mathrm{f}$ & $336,20 \mathrm{~d}$ \\
\hline F hitung & $5,27^{* *}$ & $15,35^{\star \star}$ & $7,54^{\star *}$ & $36,40^{\star *}$ \\
F tabel 5\% & 2,74 & 2,74 & 2,74 & 2,74 \\
F tabel 1\% & 4,20 & 4,20 & 4,20 & 4,20 \\
\hline BNT 5\% & 3,33 & 2,69 & 5,90 & 32,25 \\
\hline K & & & &
\end{tabular}

Keterangan:

Angka-angka dalam kolom dan perlakuan yang diikuti huruf yang sama menunjukkan tidak berbeda nyata berdasarkan Uji BNT taraf 5\%, ** = berbeda sangat nyata, $*=$ berbeda nyata, $\mathrm{tn}=$ tidak berbeda nyata.

Sutedjo (2008) dan Tohari (1993) menyatakan bahwa meningkatnya pertumbuhan vegetatif tanaman dapat berpengaruh pada meningkatnya kerja metabolisme tanaman, hasil dari metabolisme tanaman berupa protein dan karbohidrat secara cepat ditranslokasikan ke seluruh bagian tanaman untuk me- rangsang pertumbuhan vegetatif tanaman seperti pembentukan akar, batang dan daun.

Penambahan pupuk kandang ayam ke tanah mampu meningkatkan bobot basah dan bobot kering tanaman. Hal ini sesuai dengan penelitian Saragi (2008) yang menyatakan bahwa pemberian pupuk 
kandang ayam memberikan pengaruh yang nyata terhadap bobot basah tanaman dan bobot kering tanaman. Hal ini berhubungan dengan pembelahan, pembesaran dan diferensiasi sel yang menyebabkan penambahan volume. Tanaman aktif membuat sel-sel baru, pemanjangan sel dan penebalan jaringan karena keadaan fisik tanah yang baik dari pemberian pupuk kandang ayam yang menyebabkan bobot basah, luas daun dan produksi tanaman tinggi. Pengembangan batang, daun dan akar akan menambah biomassa dari tanaman tersebut.

Pengaruh interaksi intensitas cahaya dan macam pupuk kandang

Hasil penelitian menunjukkan bahwa interaksi antara intensitas cahaya dan macam pupuk kandang berpengaruh sangat nyata terhadap tinggi tanaman. Interaksi terbaik adalah pada perlakuan intensitas cahaya $100 \%$ dan macam pupuk kandang ayam (I4K1). Hal ini karena intensitas cahaya dapat membantu laju fotosintesis tanaman yang menghasilkan fotosintat. Fotosintat tidak hanya digunakan sebagai energi untuk proses metabolisme tetapi juga untuk perkembangan tumbuhan pada fase vegetatif seperti akar, batang dan daun. Penambahan pupuk kandang ayam ke tanah dapat meningkatkan per tumbuhan tanaman karena mengandung nitrogen yang lebih tinggi daripada pupuk kandang lainnya. Menurut Kononova (1966) nitrogen dapat memacu pertumbuhan vegetatif tanaman dan memberikan warna hijau pada daun. Pertumbuhan tinggi batang tidak hanya karena pengaruh media tanam, tetapi adanya faktor lain yang mempengaruhinya. Faktor lingkungan yang besar pengaruhnya terhadap pertumbuhan batang adalah suhu dan intensitas cahaya (Lakitan, 1996).

Tabel 4. Angka Rata-rata Interaksi antara Intensitas Cahaya dan Macam Pupuk Kandang terhadap Variabel Tinggi Tanaman, Panjang Akar Terpanjang, Jumlah Akar, Bobot Tanaman Tanpa Akar, Jumlah Daun, Luas Daun, Bobot Basah Tanaman dan Bobot Kering Tanaman

\begin{tabular}{ccccc}
\hline Perlakuan & $\begin{array}{c}\text { Jumlah daun } \\
\text { (helai) }\end{array}$ & $\begin{array}{c}\text { Luas daun } \\
(\mathrm{cm} 2)\end{array}$ & $\begin{array}{c}\text { Bobot basah } \\
\text { tanaman } \\
\text { (gram })\end{array}$ & $\begin{array}{c}\text { Bobot kering } \\
\text { tanaman } \\
(\mathrm{gram})\end{array}$ \\
\hline I1K1 & $14,27 \mathrm{a}$ & $91,67 \mathrm{a}$ & $75,57 \mathrm{a}$ & $2,15 \mathrm{a}$ \\
I1K2 & $13,87 \mathrm{a}$ & $88,90 \mathrm{a}$ & $76,14 \mathrm{a}$ & $2,02 \mathrm{a}$ \\
I1K3 & $14,07 \mathrm{a}$ & $84,97 \mathrm{a}$ & $69,49 \mathrm{a}$ & $1,82 \mathrm{a}$ \\
I2K1 & $16,27 \mathrm{abc}$ & $108,18 \mathrm{a}$ & $80,89 \mathrm{a}$ & $2,14 \mathrm{a}$ \\
I2K2 & $15,20 \mathrm{ab}$ & $93,86 \mathrm{a}$ & $90,61 \mathrm{a}$ & $2,50 \mathrm{a}$ \\
I2K3 & $15,73 \mathrm{ab}$ & $140,67 \mathrm{~b}$ & $146,37 \mathrm{~b}$ & $4,78 \mathrm{a}$ \\
I3K1 & $19,87 \mathrm{def}$ & $199,11 \mathrm{~cd}$ & $323,38 \mathrm{~d}$ & $13,12 \mathrm{bc}$ \\
I3K2 & $18,20 \mathrm{bcd}$ & $174,97 \mathrm{c}$ & $286,90 \mathrm{c}$ & $12,26 \mathrm{~b}$ \\
I3K3 & $19,20 \mathrm{cde}$ & $144,38 \mathrm{~b}$ & $265,91 \mathrm{c}$ & $12,54 \mathrm{bc}$ \\
I4K1 & $22,53 \mathrm{f}$ & $232,44 \mathrm{e}$ & $471,70 \mathrm{f}$ & $22,88 \mathrm{e}$ \\
I4K2 & 21,60 ef & $201,63 \mathrm{~d}$ & $358,33 \mathrm{e}$ & $15,61 \mathrm{~cd}$ \\
I4K3 & 22,20 ef & $199,67 \mathrm{~cd}$ & $372,90 \mathrm{e}$ & $17,03 \mathrm{~d}$ \\
\hline F hitung & $3,06^{\star}$ & $17,19^{\star *}$ & $48,15^{\star *}$ & $12,51^{* *}$ \\
F tabel 5\% & 2,74 & 2,74 & 2,74 & 2,74 \\
F tabel 1\% & 4,20 & 4,20 & 4,20 & 4,20 \\
\hline BNT 5\% & 3,13 & 25,72 & 30,41 & 3,10 \\
\hline
\end{tabular}

Keterangan:

Angka-angka dalam kolom dan perlakuan yang diikuti huruf yang sama menunjukkan tidak berbeda nyata berdasarkan Uji BNT taraf 5\%, ** = berbeda sangat nyata, $*=$ berbeda nyata, $\mathrm{tn}=$ tidak berbeda nyata.

Buntoro, dkk (2012) menyatakan daun merupakan organ utama untuk menyerap cahaya matahari. Tanaman yang memiliki daun yang lebar mampu menyerap cahaya matahari yang lebih banyak.
Peningkatan nilai luas daun akan menyebabkan laju asimilasinya naik dan menghasilkan berat basah dan berat kering yang tinggi. Hasil dari proses pertumbuhan dan perkembangan dapat diamati dari berat 
basah dan berat keringnya, karena berat basah merupakan hasil pengukuran dari berat basah biomassa tanaman sebagai akumulasi bahan yang dihasilkan selama pertumbuhan. Menurut Gardner, dkk (1991) berat kering merupakan akibat dari penimbunan hasil bersih dari asimilasi $\mathrm{CO} 2$ sepanjang musim pertumbuhan yang mencerminkan akumulasi senyawa organik yang berhasil disintesis tanaman dari senyawa anorganik terutama air dan $\mathrm{CO} 2$.

Penambahan bahan organik seperti pupuk kandang ayam dapat mempengaruhi pertumbuhan akar menjadi lebih baik dan lebih banyak karena pupuk kandang ayam mengandung banyak fosfor yang dapat merangsang pertumbuhan dan perkembangan akar. Tanaman yang kekurangan fosfor akan mengakibatkan perkembangan akar menjadi terhambat dan penyerapan unsur hara akan berkurang sehingga menghambat pertumbuhan tanaman bagian atas. (Hardjowigeno S, 2007).

\section{KESIMPULAN}

Berdasarkan hasil penelitian dan pembahasan dapat diambil kesimpulan sebagai berikut.

1. Perlakuan intensitas cahaya berpengaruh sangat nyata terhadap variabel tinggi tanaman, panjang akar terpanjang, jumlah akar, bobot tanaman tanpa akar, jumlah daun, luas daun, bobot basah tanaman dan bobot kering tanaman dengan pola pengaruh linier positif, sedangkan pada intensitas serangan hama dan penyakit berpengaruh nyata dengan pola pengaruh linier positif. Intensitas cahaya $100 \%$ (14) memberikan hasil terbaik pada pertumbuhan tanaman sawi putih

2. Perlakuan macam pupuk kandang berpengaruh sangat nyata pada panjang akar terpanjang, jumlah akar, bobot tanaman tanpa akar, jumlah daun, luas daun, bobot basah tanaman dan bobot kering tanaman, sedangkan pada tinggi tanaman berpengaruh nyata. Macam pupuk kandang ayam memberikan hasil terbaik pada pertumbuhan tanaman sawi putih.

3. Terdapat interaksi antara intensitas cahaya dan macam pupuk kandang terhadap semua variabel kecuali intensitas serangan hama dan penyakit. Pertumbuhan terbaik dicapai pada kombinasi intensitas cahaya
$100 \%$ (14) dan macam pupuk kandang ayam (K1).

\section{DAFTAR PUSTAKA}

Arifah, S.M. 2013. Aplikasi Macam dan Dosis Pupuk Kandang pada Tanaman Kentang. Jurnal Gamma, Volume 8, Nomor 2, http://ejournal.umm.ac.id/ index.php/gamma/article/view/2409 diakses tanggal 5 September 2016.

Buntoro, B.H. R. Rogomulyo dan S. Trisnowati. 2012. Pengaruh Takaran Pupuk Kandang dan Intensitas Cahaya terhadap Pertumbuhan dan Hasil Temu Putih (Curcuma zedoaria L.). Vegetalika Vol.3 No.4, $2014: 29$ - 39 diakses tanggal 21 Agustus 2016.

Cahyono, B. 2003. Sawi Putih Teknik Budidaya dan Analisis Usaha Tani. CV. Aneka IImu. Semarang.

Gardner, F.P., R.B. Pearce and R.L. Mitchell. 1991. Physiology of Crop Plants (Fisiologi Tanaman Budidaya, alih bahasa Herawati Susilo). UI Press. Jakarta.

Gunadi, dkk.2006. Budidaya Tanaman Paprika (Capsicum annuum var. grossum) di Rumah Plastik.Balai Penelitian Tanaman Sayuran, Lembang-

Bandung.balitsa.litbang.deptan.go.id. Diakses 12 Februari 2016.

Hardjowigeno, S. 2007. Ilmu Tanah. Mediatama Sarana Perkasa. Jakarta. Harjadi, S.S. 1991. Pengantar Agronomi. Gramedia. Jakarta.

Kononova, M.M. 1996. Soil Organic Matter. Its Nature, Role in Soil Formation and in Soil Fertility. Bergamon :Oxford, Second English Edition. Jurnal Agronomi.

Lakitan, B. 1996. Fisiologi Pertumbuhan dan Perkembangan Tanaman. P.T. Grafindo Persada. Jakarta.

Moekasan, T.K. dan L. Prabaningrum. 2011. Mitigasi Dampak Perubahan 
Iklim terhadap Serangan Organisme Pengganggu Tumbuhan (OPT) pada Tanaman Cabai Merah di Dataran Rendah. Laporan Penelitian Kerjasama Pusat Penelitian dan Pengembangan Hortikultura, Badan Litbang Pertanian, Kementerian Pertanian Republik Indonesia bekerjasama dengan Applied Plant Research and WUR Greenhouse Horticulture, Wageningen University and Research Center, the Netherlands. 16 hal.

Ribeiro, R., V. Medina, C. L. Souza, R. P. Machado, E. C. Silva. 2002. Photosynthetic response of citrus grown under reflective aluminized polypropylene shadingnets. Amsterdam. Jurnal Horticulturae (96) : 115- 125.

Risnandar, C. 2012. Jenis dan Karakteristik Pupuk Kandang. http://alamtani.com/ pupuk-kandang.html diakses tanggal 26 Maret 2016.
Samekto, R. 2006. Pupuk Kandang. PT Citra Aji Parama. Yogyakarta.

Saragi, A.H. 2008. Pengaruh Pemberian Pupuk Kandang Ayam dan Dosis Kalium terhadap Pertumbuhan dan Produksi Tanaman Peleng (Spinacia oleracea L.A). Skripsi. (dipublikasi).

Sastradihardja, S. 2014. Menanam Sayuran secara Organik. Azka. Medan Sulistyaningsih, E., B. Kurniasih, E. Kurniasih. 2003. Pertumbuhan dan Hasil Caisin pada Berbagai Warna Sungkup Plastik. Ilmu Pertanian Vol. 12 No.1, 2005 : 65 - 76 diakses tanggal 2 Februari 2017.

Sutedjo, M. M. 2008. Pupuk dan Cara Pemupukan. Rineka Cipta. Jakarta Tohari. 1993. Zat Pengatur Tumbuh. Universitas Gajah Mada. Yogyakarta Zulkarnain. 2010. Dasar Dasar Hortikultura. PT Bumi Aksara. Jakarta. 